\title{
Pre-service teachers' perception on the teaching and learning of their physical science subject methodology
}

\author{
IB Phage \\ Central University of Technology, Free State
}

\begin{abstract}
This descriptive study explores the perceptions of the second-year B. Ed. Natural Science students on their academic preparedness and perceptions on the teaching and learning of physical science subject methodology. A quantitative approach, in terms of a questionnaire, was used to collect data from 108 this group of students from a class of 142. A descriptive statistical method was used to analyse, interpret, and present data. The results indicated that students' preparedness and perceptions differed with those of those course content or programme at that level in terms of its teaching and learning approaches, class or classroom environment. They displayed fears of the subject teaching when they are supposed to get to schools for teaching practice or on their qualification and the state of training they obtain from the university. Some even recommended how teaching and learning of science in the university should be done.
\end{abstract}

Keywords: Academic perceptions, teaching practice, natural science education students, teaching and learning, subject methodology 